\title{
An Analysis of Cultural Elements in Selected Festive Advertisements
}

\author{
ISMAIL SUALMAN \\ NUURRIANTI JALLI \\ RAZWEEN MD RASHIDI \\ Universiti Teknologi MARA \\ YULIANDRE DARWIS \\ Universitas Andalas, Indonesia
}

\begin{abstract}
Cultural knowledge and understanding are fundamental in a multiracial society like Malaysia. One of the ways to foster a good relationship between people of different cultural backgrounds can be achieved through the use of media. One of the means of such a message that could be disseminated to the public is through festive advertisements. Previous studies have shown that the portrayal of culture in ads is a pivotal element that should be considered by all advertisers in producing festive advertisements. This study aims to explore whether the content of festive advertisements in Malaysia portray and deliver messages that could potentially assist in fostering a good relationship between races in Malaysia. A quantitative content analysis was done on ten festive ads. These ads were selected based on pre-determined criteria - 1) ads have to be produced by a local company, 2) uploaded on YouTube, and 3) related to the festive season. For this research, a festive ad is defined as advertisements related to festivals celebrated by the Malaysian community. Research results revealed that the majority of the selected festive ads for this study portrayed positive values that could assist in fostering good relations among people of different cultural backgrounds. The element of togetherness has been used across different festive ads to intensify the need for cross-cultural understanding, especially during festive seasons.
\end{abstract}

Keywords: Festive advertisements, content analysis, cultural elements, Malaysia.

\section{INTRODUCTION}

The world has become so connected through the increased penetration of the Internet. Globalisation made possible with technological advancement highlights the increased global pressure for embracing diversity (Khalim Zainal \& Salleh, 2010). Malaysia, a multiracial country situated in Southeast Asia, is well known for putting itself to the world, as a place of diversity. Throughout the years, even after over 60 years of independence, racial relations in Malaysia is still one of the government priorities for improvement. In contemporary Malaysia, race and religion are still two main domains for disunity among the people (Shaari, $\mathrm{Ngu}, \&$ Raman, 2006). It is imperative for all segments of the Malaysian community to assist the nation to increase understanding between the people through collective and comprehensive work.

This paper looks at the contents of advertisements, particularly festive ads in delivering positive messages related to unity and togetherness, especially among people of different races. In this study, positive messages refer to the notion proposed by Heath and Hyder (2005) which any ad that has on optimistic tone, encouraging viewers to embrace the idea of togetherness and unity, as well as accepting values widely accepted by the local community. It is undeniable that the primary way to increase understanding among people, especially of those different racial backgrounds, is through effective communication. 
Communication is a process of sending information through effective deliverance of message to its intended recipients (DeVito, 2016) using various media such as text, images, spoken words, etc. In the current globalised world, it can be seen that advertising is becoming a tool for improving togetherness. Many advertising companies, including in Malaysia, took the initiative to create ad content to push for better racial relations in the nation. For example, local companies such as Petronas, Maxis, Celcom among others that came up with visually exciting content to push for this agenda (Haque, Al Mahmud, Tarofder \& Ismail, 2007; Zubir, 2012).

Also, daily interactions and communication among the diverse Malaysian community should be improved to increase tolerance and understanding among the people. Effective intercultural communication would assist people in increasing knowledge about other races and deepens the sense of unity among the community (Samovar, 2014). Having a good grasp of intercultural communication would help a person to have a different perspective on other cultures, and effective communication can be created. Sarjit (2012) posited that unity and national incorporation have been the main agenda of this country since the old days up until now. Integration is one of the elements that play a crucial role in helping Malaysians maintain its state of peacefulness it enjoys today. Misunderstanding among races, especially of those minority groups towards the Malay dominant, would not only lead to racial disunity but would result in national security jeopardy (Guan, 2002).

\section{PROBLEM STATEMENT}

Festive advertisements that contain high cultural values can be a motivational tool for all Malaysians to realize the importance of the harmony and peacefulness of this country. Wellportrayed festive ads that are full of cultural values are good examples to all people in strengthening the value of togetherness (Bollnow, 1989) among people of different races. In addition to that, these advertisements are also able to build trust among people of diverse cultural backgrounds and ethnicity to be able to rely on each other (Li, 2011). For this research, the cultural values found in selected festive advertisements would help in understanding the influence of media content towards strengthening racial relations. It is undeniable that ads do play a critical role in promoting good cultural values, especially during festive seasons, whereby most of the advertisements touch the heart of its viewers.

Khalim Zainal and Salleh (2010) asserted that there are still unsolved problems in contemporary Malaysia when it comes to acceptance and understanding between people of different races. This notion has been echoed by many scholars (Haque, 2003; Mustapha, 2009; Soong, 2008), therefore it is worthy for researchers to explore on this issue through the perspective of advertising. The researchers aimed to explore whether the selected festive advertisements use the element of togetherness and unity among people of different cultural backgrounds. This will assist in realising the importance of such message towards nation building. In another study, Siti Zabedah (2013) found that there were some films produced by local producers such as the late Yasmin Ahmad and Petronas that contain valuable messages regarding unity or togetherness which involve the Malay, Chinese and Indian ethnic groups. These media content became good examples for local producers to create media products centralising on the same message. This research looks at the content of selected festive advertisements in Malaysia. By studying the content through content analysis, this study aims to look at messages contained in selected festive ads, with specific focus on cultural elements. The researchers also look the themes commonly highlighted by advertisers in promoting good intercultural relationship and community togetherness in Malaysia regardless of the multiracial societal background. 


\section{Roles of Advertising}

\section{LITERATURE REVIEW}

According to Holladay (2010), advertising is a fundamental tool to promote the existence of products in the market and provide information to consumers about the details of products, services or campaigns that have been advertised. In other words, advertising is a one-stop place that provides all information about products, services, or even campaigns for the public. A wealth of information can be obtained from a single advertisement for a product, service, or campaign (Khan, 2011).

In a paper by Baharuddin and Saniah (2017), it was explained that advertisements are one of the best marketing tools and a paid form that can convey messages to consumers. Additionally, both researchers also stated that culture plays a vital role in advertising, as it will show whether certain advertisements are effective or vice versa. Another reason why the cultural aspect is essential in the ad is that not all people share the same cultural values. Therefore, it is important for advertisers to carefully analyse an audience's culture so that the messages can be well conveyed through advertisements. In addition to that, being able to understand a person's cultural values will help us to be more appreciative of other people's style or way of life. By understanding other people's view of the world and culture, viewers would be more accepting of social and cultural differences (Freedman, 2003).

It can be said that advertising is one of the tools that is very important in the marketing industry with the help of new media. In relation to this research, advertisements have helped in cultivating the feeling of togetherness among Malaysians (Nooh, Khairi, Abdullah, \& Shukor, 2014). Well produced ads composed with positive messages promoting tolerance towards different cultures will assist Malaysians in realising that unity in Malaysia is an essential value in a diverse community (Shariff, Sualman, \& Iraman, 2013). With a declining sense of unity among the younger generation in Malaysia (Chang, 2016), there is a dire need for cultivation of the sense of belonging towards the nation regardless of different races and increased tolerance towards people of a different culture. Ongoing competitiveness among people of different races in Malaysia also influences the continuing discomfort and halted unity among Malaysians (Yeoh \& Yeoh, 2019).

\section{Cultural Values in Advertisements}

Pollay (2012) stated that since advertising plays a significant role in mass media, it is vital to portray cultural values in advertisements in addition to cultivating the values at schools, in a family institution as well as universities and military schools. In addition to that, advertising also managed to educate those who viewed the advertisements.

The researcher also stated that sometimes values portrayed in advertisements are quite direct, and the researcher pointed out an example of a Kodak advertisement whose tag line was 'Trust Kodak.' The tag line touches on the value of trustworthiness among viewers. It also indirectly had cultivated trust in Kodak among viewers. By reading the slogan, it managed to attract readers by stating that they should put their trust in Kodak instead of another brand because Kodak was, then, the best product when it came to photography.

There are a few important values in advertising such as morality, truthfulness, and social responsibility (Nwachukwu, Vitell, Gillbert \& Barnes, 1997; International Chamber of Commerce, 2011). The definitions of these values can be found below: 
I. According to International Chamber of Commerce (2011), morality in advertising in the use of texts (written, images, etc) and verbal expressions should not go against moral principles of the society. If the advertisement goes against the community standard, that particular advertisement should not be published.

II. Truthfulness in advertising refers to the act of giving true information or facts (in exact manner) about something (Kehinde, 2009) and,

III. Social responsibility in advertising focuses on not publishing anything that contains discrimination, hatred, religion, sex, and demoralises human dignity (International Chamber of Commerce, 2011).

In the context of this research, by incorporating these three values in cultural advertisements with the specific aim to cultivate tolerance and sense of unity, the optimum impact can be transmitted to the audiences. According to Wan Amizah, Chang Peng Kee and Jamaluddin Aziz (2009), in the diverse Malaysian community, cultural elements in media production has to be treated delicately. This can be seen through the implementation of various laws by the government to monitor media content in Malaysia which is sometimes deemed as restrictive by media producers (Jalli, 2016). However, the government justifies the need to implement stringent laws to ensure that the public is more aware of the legal predicaments when failing to respect the multicultural Malaysian society (Wan Amizah et al., 2009).

\section{Hofstede's Cultural Dimensions}

Geert Hofstede is a well-known philosopher when it comes to cultural studies and understanding of people as well as their cultural values. Hofstede (2011) in his paper, listed the major cultural dimensions that are said to be able to explain a country's norms and values. The five cultural aspects, as explained by Hofstede (2011) are power distance, individualism/collectivism, masculinity/ femininity, high/low uncertainty avoidance and lastly, time orientation.

Power distance can be referred to as the degree of inequality that exists in a society. High power distance means that there is a boundary between the people. For instance, leaders who want to gain more respect will place themselves in a higher position, and the people need to understand their place in relation to that higher position. Meanwhile, low power distance is associated with people who share their power, and the power is well used between the people. For instance, people who possess low power distance value will treat others just like how they want to be treated. There is no boundary between them. The second dimension is individualism. This particular dimension refers to the strength of bonds that people have within a community. High individual scores prove that a particular person has a loose connection with other people around him or her.

A person who has a high individual score is said to have small interpersonal interactions and only share certain things or thoughts with other people. Additionally, this particular person also demands privacy and their own freedom. On the other hand, a person with a low individual score will always seek people's opinions and at the same time, engage in discussions with others. Individuals who have this characteristic will also tend to focus on maintaining harmony because everyone's opinions matter. According to Hofstede (2011), a community with a lower individualism score is identified as a collectivistic society. In Malaysia specifically, Hofstede Insight (2019), a cultural index website, classified Malaysia as a collectivistic society through observation that many Malaysians still commit to a long- 
term commitment to the "member" group, "be that a family, extended family or extended relationships' (Hofstede Insight, 2019).

The third dimension is masculinity. This dimension suggests that in a community with high masculinity, the community will be driven by competition, achievement, and success. Success will be defined by the best achiever in the field - a value imbedded in the macro system including the educational framework. A high femininity community suggests that the community values quality of life and caring for one another. The fourth dimension is uncertainty avoidance. This dimension explains the level of anxiety a person feels when he or she is in uncertain or unknown situations. People with a high degree of uncertainty avoidance tend to have formal conversations or business conduct with a lot of rules and regulations due to the person in charge being afraid of what is going to happen in the future. A low level of uncertainty avoidance focuses on maintaining relationships between people for a more extended period. A person who has this particular element is a person who accepts changes and is not afraid of the future risks.

The last dimension as proposed in Hofstede's cultural dimensions is the long-term orientation that refers to how much a society values the traditions and values in that society. Among the characteristics of high long-term orientation are putting family as the primary basis of the family institution, where older people are seen to have more authority and should be respected. Meanwhile, low long-term orientation focuses on promoting equality, high levels of individualism, and self-actualisation as needed in society. Another study by Gromova, Muglova and Perez (2017) also emphasised the five cultural dimensions proposed by Hofstede to construct as well as analyse the cultural elements contained in an advertisement.

The dimensions are necessary to help international and local advertisers understand the needs and demands of their audiences. In addition to that, it is also emphasised that advertising does not only focus on and evaluate the verbal or non-verbal communication but also the cultural aspects portrayed in it.

Based on the five dimensions proposed and explained in Hofstede's cultural dimensions, we found that a few elements related to masculinity/femininity, individualism, and long-term orientation (see Table 2 for details) can be used to analyse the concept of unity among the multi-racial society in Malaysia. This is because Malaysians are made up of people with different cultural backgrounds. Hence, it is crucial to know the essential cultural characteristics of a person first to understand that person well. For this research, these three elements were selected to analyse the content of the festive advertisements.

\section{RESEARCH METHODOLOGY}

In an article by Ngulube and Mathipa (2015), Thomas Kuhn defined a research paradigm as a research culture with a set of beliefs, values, and assumptions that a community of researchers has in stock to conduct their research. For this particular research, a quantitative paradigm is utilised. More specifically, quantitative content analysis was utilised to analyse the selected festive advertisements. Typically associated with the qualitative research paradigm, content analysis can assist researchers in systematically evaluating media content (Rose, 2015) and the data obtained can be converted into quantitative data (McCombs, 2002). For this research, both qualitative and quantitative elements to content analysis were employed. While a qualitative approach to content analysis was used to identify the cultural elements portrayed in 10 selected ads, a quantitative approach was employed to illustrate findings. Later, chi-square tests were 
conducted to examine the cross-tabulation between positive values found in selected festive commercials. The chi-square tests conducted would assist in determining whether or not festive advertisements by local producers contain positive values that will assist in fostering good relations among people of different cultural backgrounds. The ten festive ads were selected based on these pre-determined criteria:

1. Produced by Malaysian companies.

2. Ads uploaded on YouTube.

3. Related to festive seasons in Malaysia.

Table 1: List of festive ads selected for content analysis

\begin{tabular}{cccl}
\hline No. & Festive season & Year & \multicolumn{1}{c}{ Title } \\
\hline 1 & Eid/Hari Raya & 2016 & Vroom-vroom \\
2 & Eid/Hari Raya & 2017 & Donut ke karipap? \\
3 & Chinese New Year & 2016 & Rubber boy \\
4 & Chinese New Year & 2018 & A long way home \\
5 & Deepavali & 2016 & I am Muniandy \\
6 & Deepavali & 2017 & Arathi's first love \\
7 & Gawai & 2017 & Siapa Jojo? \\
8 & Gawai & 2018 & Home is calling \\
9 & National Day & 2016 & Take care \\
10 & National Day & 2017 & Piala Taman Thomas \\
\hline$N=10$ & & &
\end{tabular}

The accumulated length for all 10 ads was 33 minutes 44 seconds. To simplify the process of analysis, the researchers divided the ads into smaller units (15-second/scene). A total of 134 scenes were generated and later analysed using a coding sheet. The coding sheet was developed to guide the researchers in identifying the elements of unity and togetherness in the selected ads. The coding sheet includes units to assist in identifying the main theme of each advertisement, as well as identifying the elements of unity and togetherness. The intercoder reliability index for this study was at 0.75 (k, Cohen's Kappa index). According to Lombard, Snyder-Duch and Bracken (2002), 0.75 is an acceptable rate.

Table 2: Some of the units included in the coding sheet

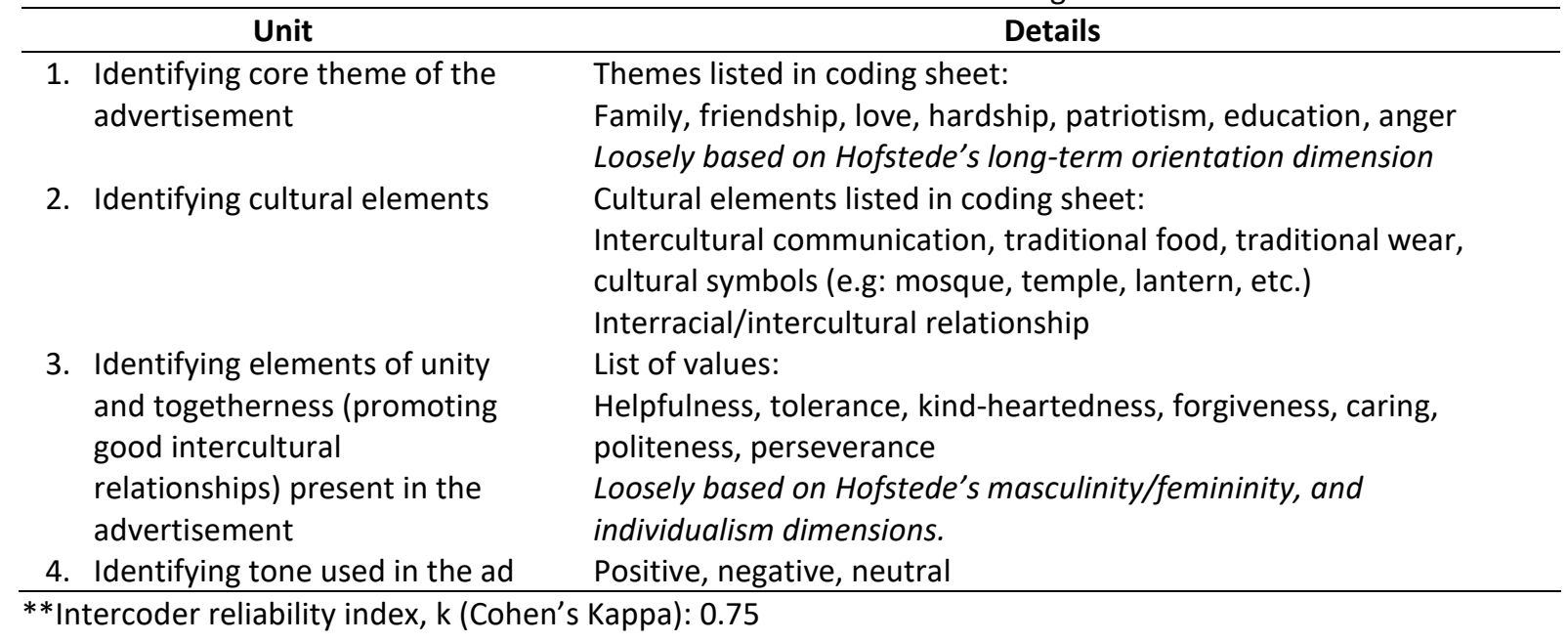


Data collection management explains the steps of how a researcher conducts research such as the selection of data source, the process of collecting data, and finally, how the data leads to the objectives of this research. The method of data collection in this study is listed in Figure 1 below:

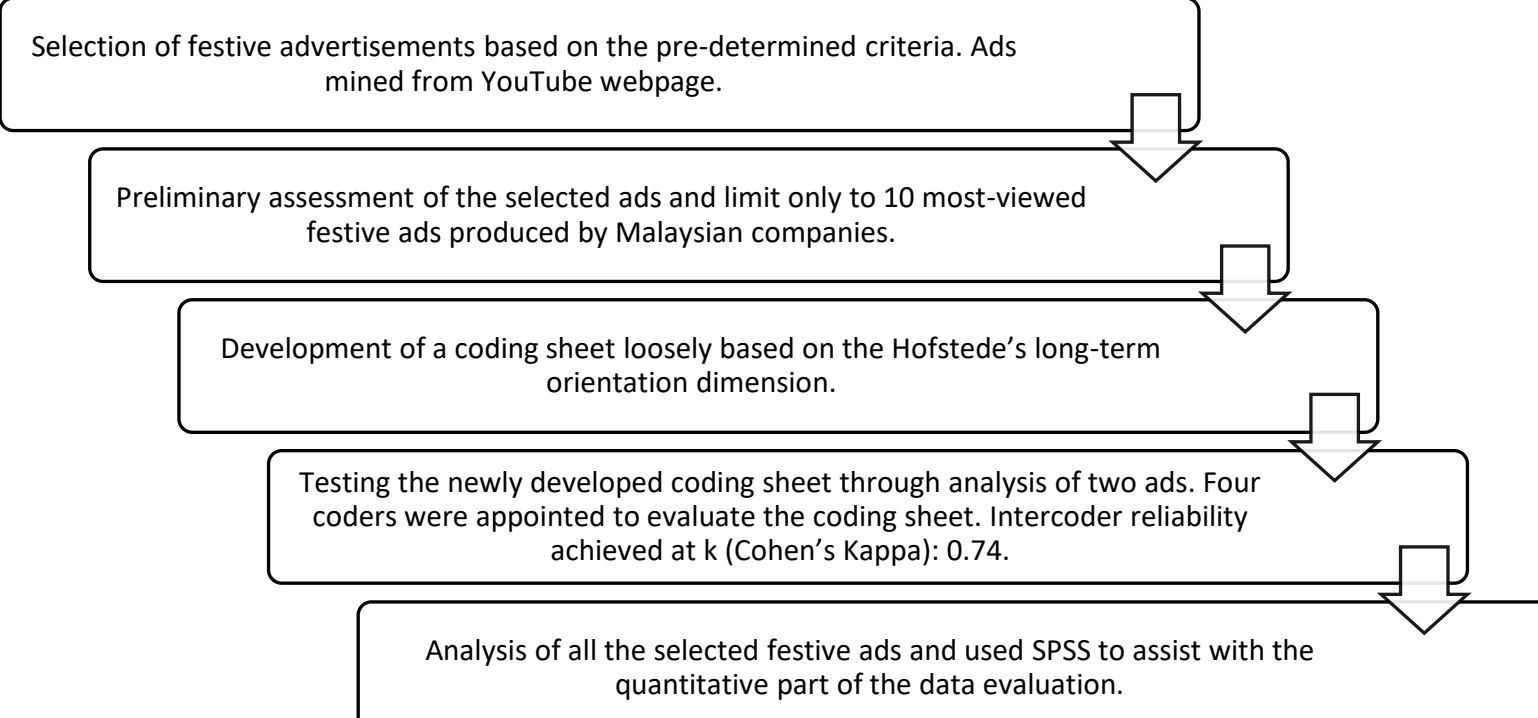

Figure 1: Data collection process

\section{FINDINGS}

Through content analysis of two Petronas advertisements, the result revealed that there was a shift in culture representation from Vroom Vroom (2016) and Donut ke Karipap (2017). While in Vroom Vroom (2016) the content focused solely on the story of a Malay family, the Donut ke Karipap (2017) advertisement showcased a group of multiracial children learning to respect the holy month of Ramadhan (Figure 2). Here (in Donut ke Karipap) it could be seen that through the presence of a multiracial society in a Hari Raya ad, the advertiser subliminally suggests for interracial tolerance. This element also related to one of the dimensions proposed by Hofstede (2011), which is long-term orientation. Unlike in homogenous communities in nation-states such as Japan and Israel, Malaysia is unique due to its diverse population. To uphold racial harmony in the country, media has to play an active role in promoting positive interracial elements in their media content.

The next festive advertisements chosen were two Chinese New Year advertisements. The first one was the advertisement in 2016 entitled Rubber Boy. In Rubber Boy, the advertiser portrayed the hardship of a Chinese family whereby the mother only worked as a rubber tapper to support their living. In addition to that, the advertiser also highlighted the value of being thankful with what we have. Meanwhile, in the Chinese New Year 2018 advertisement entitled A Long Way Home, the advertiser portrayed the relationship between a father and his son who had different views and opinions towards his future, but in the end, the son realised that his father's love towards him was endless and will always make him feel at home. It portrayed the importance of family values when it comes to decision making, and the way festivals help families to reunite. The main message put forward in these two advertisements were representative of what Hofstede (2011) posited as the long-term orientation dimension as described previously. 
Two advertisements that were chosen for Deepavali celebration were an advertisement in 2016 entitled I Am Muniandy and one from 2017, Arathi's First Love. I Am Muniandy tells a story about Muniandy and his friend who were very kind to help an aunty to clean the compound of an old folk's home. This advertisement portrayed how kindness can unite people from different walks of life. Meanwhile, Arathi's First Love showcases a group of children with diverse cultural backgrounds and races. It portrayed friendship and the importance of forgiveness. This particular advertisement taught viewers that it was imperative to seek for others' forgiveness whether we had hurt that person or not especially during festive seasons because forgiveness will be able to reunite those who were previously cold towards each other. It also highlighted the importance of friendship whereby good friends stay during good and bad times. The subliminal promotion of good interracial relationships in Arathi's First could be related to the Hofstede (2011) individualism dimension.

The next advertisements that were selected by researchers were two National Day advertisements between 2016 and 2017, respectively. The first one was the National Day 2016 advertisement entitled Take Care. This particular advertisement portrayed several families of different cultural backgrounds and how the value of kindness had helped all of them to have a better relationship with each other and at the same time strengthened unity among the multiracial families. In the National Day 2017 advertisement entitled Piala Taman Thomas, the story was about a group of children with different cultural backgrounds who competed with two competitive men. The men were selfish and did not want to share the badminton court with the children. All the interracial encounters in both ads centralised on the individualism dimension and could also be related to the masculine/feminine dimension as proposed by Hofstede (2011).

Lastly, two Gawai advertisements were selected from many ads produced by Petronas. The first one was a Gawai 2017 advertisement entitled Siapa Jojo? This particular advertisement was full of portrayals of cultural elements such as the Rumah Panjang, the way Sarawakians sit down to have their meals and the way Sarawakians celebrate their Gawai festival. This advertisement also portrayed a group of people with different cultural backgrounds involved in the Gawai celebration. In addition to that, this particular advertisement also utilised the buffalo as a symbol of hard work. The grandfather tried to teach the grandchildren to appreciate all the living things around them. On the other hand, the Gawai 2018 advertisement entitled Home Is Calling portrayed a man who at first was reluctant to go back to his hometown for Gawai but after some thoughts and imagining the happiness at home, he decided to go back to his hometown to celebrate the Gawai festival with his family, especially his mother. These moments portrayed how a small act can help to strengthen the bond and unity between families. In addition to that, the advertisement also highlighted that the happiness received when we value our family is priceless.

\section{Cultural Elements Used in Selected Festive Advertisements in Malaysia}

A sum of 134 scenes from 10 festive advertisements were analysed. Table 3 below presents the findings of percentage of positive values and content of the selected festive adertisements according to the chosen festivals, which were Hari Raya, Chinese New Year, Deepavali, National Day, and the Gawai celebration (see Figures 2 and 3). Intercoder reliability for this analysis is 0.73 ( $\mathrm{k}$, Cohen's Kappa index). It was found that Hari Raya advertisements showcased the most positive values in its scenes. This was due to the messages conveyed in the Hari Raya advertisements being associated with the holy month of Ramadhan where Muslims focus on the act of worship (ibadah) and to pursue kindness 
regardless of differences. In both Hari Raya advertisements, positive values are not only portrayed by Malay Muslims, but also by actors of different races and religions.

Table 3: Percentage of positive message/ whole clip (\%)

\begin{tabular}{|c|c|c|c|c|c|c|}
\hline Festive ads & Title & $\begin{array}{l}\text { Main } \\
\text { themes } \\
\text { found }\end{array}$ & Cultural elements & $\begin{array}{l}\text { Two main } \\
\text { values found } \\
\text { (not limited } \\
\text { to) }\end{array}$ & Tone & $\begin{array}{l}\text { Percentage of } \\
\text { positive } \\
\text { message/whole } \\
\text { clip (\%) } \\
\end{array}$ \\
\hline \multirow[t]{3}{*}{$\begin{array}{l}\text { Eid/Hari } \\
\text { Raya }\end{array}$} & Vroom-vroom & Family & $\begin{array}{l}\text { Multiracial characters, } \\
\text { Malay-speaking } \\
\text { characters, Singh-turban } \\
\text { worn by a Singh } \\
\text { character, Raya songs. }\end{array}$ & $\begin{array}{l}\text { Perseverance, } \\
\text { caring }\end{array}$ & Positive & $78 \%$ \\
\hline & $\begin{array}{l}\text { Donut ke } \\
\text { karipap? }\end{array}$ & Friendship & $\begin{array}{l}\text { Multiracial characters in } \\
\text { the ad, Malay Muslim, } \\
\text { cultural symbols - kopiah } \\
\text { for Muslim prayers. }\end{array}$ & $\begin{array}{l}\text { Tolerance, } \\
\text { perseverance }\end{array}$ & Positive & $83 \%$ \\
\hline & Rubber boy & Hardship & $\begin{array}{l}\text { Chinese speaking } \\
\text { characters, Buddhist } \\
\text { altar, incense, }\end{array}$ & $\begin{array}{l}\text { Tolerance, } \\
\text { forgiveness }\end{array}$ & Positive & $72 \%$ \\
\hline \multirow[t]{2}{*}{ New Year } & $\begin{array}{l}\text { A long way } \\
\text { home }\end{array}$ & Family & $\begin{array}{l}\text { Chinese speaking } \\
\text { characters, Chinese } \\
\text { lanterns, lion dance. }\end{array}$ & $\begin{array}{l}\text { Caring, } \\
\text { forgiveness }\end{array}$ & Positive & $74 \%$ \\
\hline & $\begin{array}{l}\text { I am } \\
\text { Muniandy }\end{array}$ & Friendship & $\begin{array}{l}\text { Indian cultural symbols, } \\
\text { Tamil-speaking } \\
\text { characters, other races } \\
\text { present - Malay, }\end{array}$ & $\begin{array}{l}\text { Caring, kind- } \\
\text { heartedness }\end{array}$ & Positive & $71 \%$ \\
\hline \multirow[t]{2}{*}{ Deepavali } & $\begin{array}{l}\text { Arathi's first } \\
\text { love }\end{array}$ & Friendship & $\begin{array}{l}\text { Chinese, Indian. } \\
\text { Indian cultural symbols, } \\
\text { other races present - } \\
\text { Malay, Chinese, Indian. }\end{array}$ & $\begin{array}{l}\text { Forgiveness, } \\
\text { perseverance }\end{array}$ & Positive & $73 \%$ \\
\hline & Siapa Jojo? & Friendship & $\begin{array}{l}\text { Iban cultural symbols - } \\
\text { Iban long house, Iban } \\
\text { 'bunga terung' tattoo, } \\
\text { other races present - } \\
\text { Malay, Chinese }\end{array}$ & $\begin{array}{l}\text { Perseverance, } \\
\text { helpfulness }\end{array}$ & Positive & $78 \% \%$ \\
\hline Gawai & $\begin{array}{l}\text { Home is } \\
\text { calling }\end{array}$ & Family & $\begin{array}{l}\text { Iban-speaking characters, } \\
\text { Iban traditional food, rice } \\
\text { wine, Iban traditional } \\
\text { costume }\end{array}$ & $\begin{array}{l}\text { Caring, } \\
\text { politeness }\end{array}$ & Positive & $82 \%$ \\
\hline National & Take care & Love & Multiracial characters & $\begin{array}{l}\text { Caring, } \\
\text { politeness }\end{array}$ & Positive & $79 \%$ \\
\hline Day & $\begin{array}{l}\text { Piala Taman } \\
\text { Thomas }\end{array}$ & Patriotism & Multiracial characters & $\begin{array}{l}\text { Perseverance, } \\
\text { politeness }\end{array}$ & Positive & $81 \%$ \\
\hline
\end{tabular}

**Scenes for each ad were divided into 15-second scenes. Intercoder reliability was 0.73 (k, Cohen's Kappa index)

Other selected festive advertisements such as for Chinese New Year, Deepavali, National Day, as well as Gawai celebration also portrayed the positive values throughout the scenes in the commercials. It was found that the most depicted value is caring. Through the lens of Hofstede (2011), most selected ads portrayed Malaysia as a feminine nation (caring) and low in individualistic values. Almost all advertisements highlighted the importance of caring, especially toward family members. The most common message was that at the end of the day, a person only has their family to rely on in life. The results in the table above showed that festive advertisements that contain positive values have the potential to influence the cultivation of positive values among the multicultural society in Malaysia. 


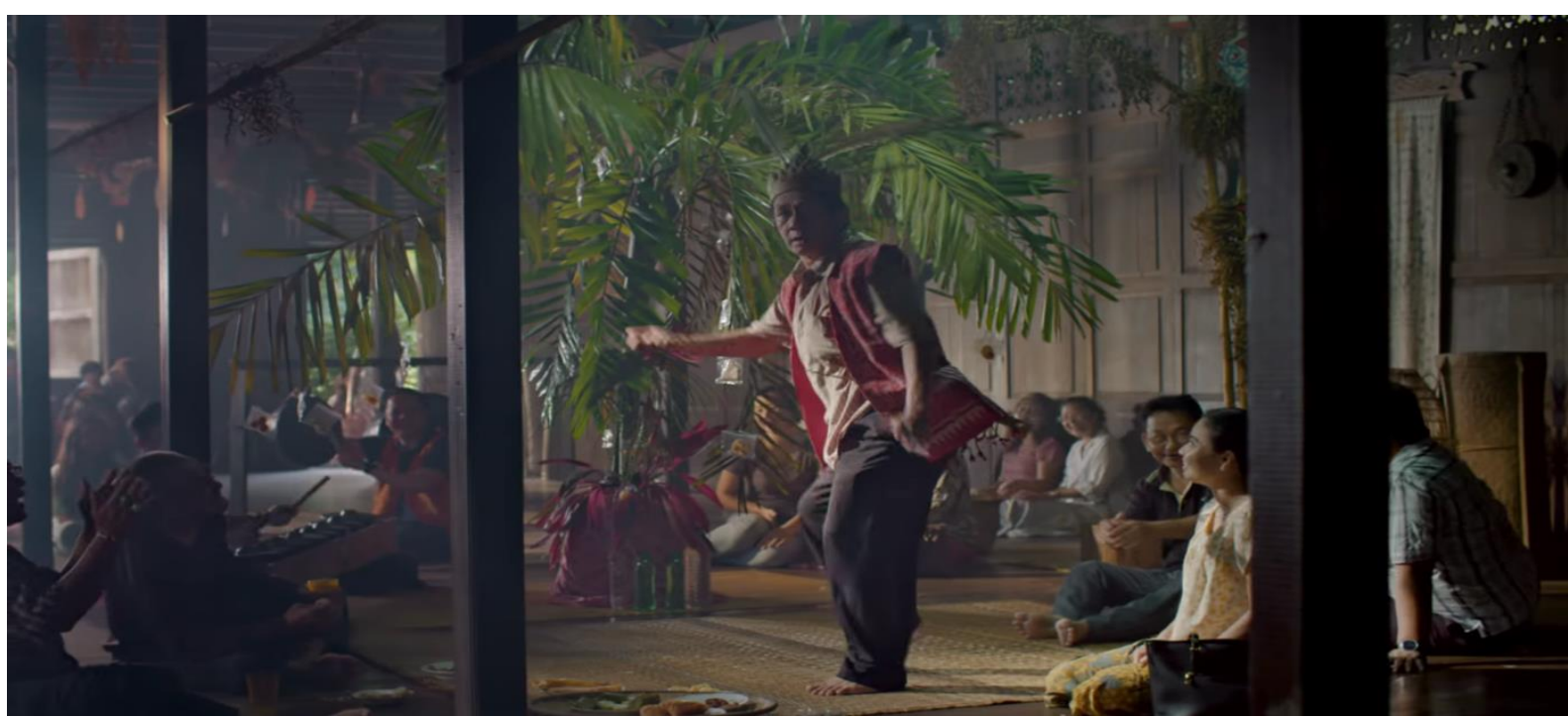

Figure 2: Cultural elements in "Home is calling" festive ad for Gawai/Kaamatan. Clear shots of Iban cultural symbols such as Iban headgear, traditional machete, food, longhouse, and jacket made of traditional Dayakmotif textile.

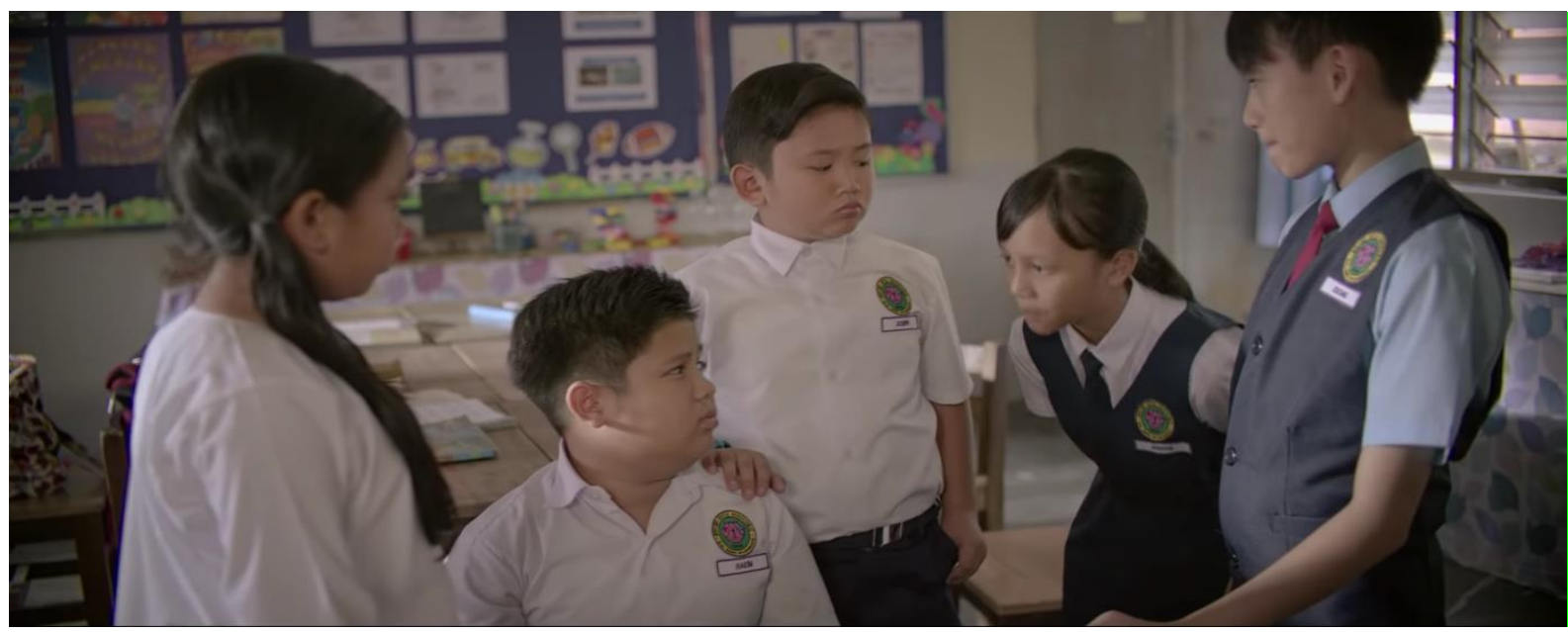

Figure 3: Multi-racial characters in "Donut ke Karipap" festive ad. Hakim the main character is a Malay Muslim, attending a public school in Malaysia.

Table 4 displays the result of the themes found in the selected festive advertisements and the characters used. The two most represented ideas in selected festive ads were family and friendship, followed by love, hardship and patriotism. The theme of family and friendship were highlighted in almost all festive advertisements. It was found through a review of ad content that advertisers often use the element of humans as social creatures (Read \& Miller, 1995 ) as the focal point in their festive advertisements. Highlighting this element in pursuance of cultural aspects would potentially increase the impact on viewers. Both themes portrayed the importance to value our family members as well as our friends. This is due to family members, and close friends might be there in times of need. Based on Hofstede (2011), we found that content produced by advertisers tend to portray Malaysian plural society as feminine and less individualistic.

The selected festive advertisements also portrayed that no matter how distant people might have been with family members throughout the year, they will always reunite with them, especially during the festive season. Close friends are also a group of people that still visit friends and family to maintain the bonds between them. This element is parallel to 
Hofstede's (2011) long-term orientation dimension. The cross-tabulation of themes and characters showed the significance of each issue being utilised in each festive advertisement. By highlighting the need for human beings to socialise be it with family and close friends, advertisers could leave a more significant impact on viewers through subliminal message delivery (Leiss, Kline \& Jhally, 1990).

Table 4: The themes of selected festive advertisements and the characters used

\begin{tabular}{|c|c|c|c|}
\hline Festive ads & Title & $\begin{array}{l}\text { Main themes } \\
\text { found }\end{array}$ & Characters used \\
\hline \multirow{4}{*}{$\begin{array}{l}\text { Eid/Hari } \\
\text { Raya }\end{array}$} & Vroom-vroom & Family & $\begin{array}{l}\text { A Malay father and son relationship - went through } \\
\text { hurdles and chased away from home. Characters present }\end{array}$ \\
\hline & & & $\begin{array}{l}\text { including Singh security guard, Chinese landlord, among } \\
\text { others. }\end{array}$ \\
\hline & $\begin{array}{l}\text { Donut ke } \\
\text { karipap? }\end{array}$ & Friendship & $\begin{array}{l}\text { Friendship of multi-racial characters assisting Hakim, the } \\
\text { main character to fast in the month of Ramadhan. }\end{array}$ \\
\hline & Rubber boy & Hardship & $\begin{array}{l}\text { Chinese mother and a child bittersweet relationship } \\
\text { portrayed through flashback of past memories. }\end{array}$ \\
\hline New Year & $\begin{array}{l}\text { A long way } \\
\text { home }\end{array}$ & Family & $\begin{array}{l}\text { Rocky relationship between son and father portrayed } \\
\text { through conversation during a drive back to the } \\
\text { characters' hometown. }\end{array}$ \\
\hline \multirow[t]{2}{*}{ Deepavali } & $\begin{array}{l}\text { I am } \\
\text { Muniandy }\end{array}$ & Friendship & $\begin{array}{l}\text { Friendship between two young men with a caretaker of } \\
\text { old folks' home in Cheras. }\end{array}$ \\
\hline & $\begin{array}{l}\text { Arathi's first } \\
\text { love }\end{array}$ & Friendship & $\begin{array}{l}\text { Friendship between multiracial characters with main } \\
\text { character is Arathi, an Indian girl. }\end{array}$ \\
\hline & Siapa Jojo? & Friendship & $\begin{array}{l}\text { Friendship between multiracial characters set at a } \\
\text { longhouse in Sarawak. }\end{array}$ \\
\hline Gawai & $\begin{array}{l}\text { Home is } \\
\text { calling }\end{array}$ & Family & $\begin{array}{l}\text { An Iban man working away from hometown contacted by } \\
\text { a family member in Sarawak. The main characters } \\
\text { reminiscing Gawai celebration in his hometown } \\
\text { (multiracial characters although majority characters in } \\
\text { the ad were Iban). }\end{array}$ \\
\hline & Take care & Love & Chinese schoolteacher and a Malay pupil. \\
\hline $\begin{array}{l}\text { National } \\
\text { Day }\end{array}$ & $\begin{array}{l}\text { Piala Taman } \\
\text { Thomas }\end{array}$ & Patriotism & $\begin{array}{l}\text { Former national badminton champions (Thomas Cup), } \\
\text { Foo Kok Keong and Rashid Sidek interacting with a group } \\
\text { of multi-racial young students. }\end{array}$ \\
\hline
\end{tabular}

\section{CONCLUSION}

Advertisements serve not only as marketing tools for consumer products but also as a proponent for cultural promotions (Aziz, Azlan \& Ahmad, 2011). Through our analysis, results revealed that content producers for the selected Malaysian festive ads tend to centralise on the three Hofstede (2011) cultural dimensions, which are the long-term dimension, masculinity/femininity dimension, and individualism dimension. We conclude that Malaysian festive ads portray the plural Malaysian society as a feminine and less individualistic community where the people care towards one another and long for good relationships amongst one another. The selected festive ads also tend to play with tangible cultural elements such as the Islamic house of worship, the mosque, for Hari Raya advertisements, or red lanterns to represent Chinese festivals. Both subliminal and apparent messages promoting good interracial relationships were also found across most of the festive advertisements studied. In the current Malaysian landscape, where there is a need to improve interracial relations, advertisers of the advertisements analysed were found to be supportive of the agenda through the promotion of positive interracial 
relationships. Other than that, we also noticed that selected ads also promoted each culture individually according to the chosen festival. For example, Gawai Dayak, the festive ad contains tangible cultural objects to promote the Dayaks and their lifestyles (like the Iban longhouse) on top of relatable societal values such as kindness, respect, or caring towards family members. Results revealed that selected commercials push for positive messages, the core element of togetherness and unity not only found through the portrayal of crossculture interactions but also within family institutions. By playing with such sentiments, relatable for the feminine Malaysian society, it is believed that advertisers can influence the instillation of positive values among audiences. Advertisers must fulfil their social responsibility through the promotion of positive societal tenets to assist in improving racial relations in Malaysia, as well as in the outset, reinforcing family values. This research is significant in highlighting the cultural elements often used by advertisers in Malaysia. Through this research, advertisers can learn the optimum ways to promote cultural values and the necessary elements to increase the impact of the messages in the commercials. Now, with the availability of various media, particularly ones powered by the Internet, advertisers have to be more proactive in grabbing audiences' attention. Creative skills, mastering the art of knowing 'what sells' and understanding Malaysian society are essential in creating culturally related artwork, which in this case is festive advertisements.

\section{BIODATA}

Ismail Sualman is a Professor in Communication at Faculty of Communication and Media Studies and Director of Centre for Media and Information Warfare Studies, Universiti Teknologi MARA, Shah Alam Selangor. Email: ismailsu1110@gmail.com

Nuurrianti Jalli is an Assistant Professor of Communication Studies at the Department of Languages, Literature, and Communication Studies at the Northern State University. Her research interests are studies related to media, democracy, information disorder, and information literacy in Southeast Asia. Email: nuurrianti.jalli@northern.edu

Razween Md Rashidi is a Journalist and Writer. Her research interest is studies related to media and communication. Email: razweenrashidi@gmail.com

Yulianandre Darwis is a Seniour Lecturer at Faculty of Communication, Universitas Andalas, Padang, Indonesia. Email: yuliandre.darwis@gmail.com 


\section{REFERENCES}

Aziz, J., Azlan, A. A., \& Ahmad, A. L. (2011). Characterisation and leitmotif: Archetypal imageries in Malaysian festival TV advertisements. Jurnal Komunikasi: Malaysian Journal of Communication, 27(2).

Baharuddin, M. A., \& Saniah, A. (2017). A semiotic analysis and cultural values of Malaysian automotive TV advertisements. Gendang Alam, 35-52.

Nooh, M. N., Khairi, K. F., Ab Aziz, M. R., Abdullah, M., \& Shukor, S. A. (2014). The criteria and challenges of unethical advertising. American Journal of Business, Economics and Management, 2(4), 88.

Bollnow, O. (1989). Ceremonies and festive celebrations in the school. Phenomenology+ Pedagogy, 7, 64-78.

Chang, L. W. (2016). National unity at the university level: An exploratory study at the University of Malaya/Chang Lee Wei [Doctoral dissertation, University of Malaya].

DeVito, J. A. (2016). Essentials of human communication. Pearson

Freedman, D. (2003). Acceptance and alignment, misconception and inexperience: Preservice teachers, representations of students, and media culture. Cultural Studies? Critical Methodologies, 3(1), 79-95.

Gromova, E., Muglova, D., \& Perez, E. (2017). Culture in advertising and advertising in culture: Communication, translation, representation. Degruyter, 81-92.

Guan, L. H. (2002). Malay dominance and opposition politics in Malaysia. Southeast Asian Affairs, 177-195.

Haque, A., Al Mahmud, S., Tarofder, A. K., \& Hj Ismail, A. Z. (2007). Internet advertisement in Malaysia: A study of attitudinal differences. The Electronic Journal of Information Systems in Developing Countries, 31(1), 1-15.

Haque, M. S. (2003). The role of the state in managing ethnic tensions in Malaysia: A critical discourse. American Behavioral Scientist, 47(3), 240-266.

Heath, R., \& Hyder, P. (2005). Measuring the hidden power of emotive advertising. International journal of market research, 47(5), 467-486.

Hofstede Insight. (2019). Cultural country comparison: Malaysia. https://www.hofstedeinsights.com/country-comparison/malaysia/

Hofstede, G. (2011). Dimensionalizing cultures: The Hofstede model. Online Readings in Psychology and Culture, 2(1). https://doi.org/10.9707/2307-0919.1014

International Chamber of Commerce. (2011). ICC consolidated code of advertising \& marketing practice. The world business organization.

Jalli, N. B. (2016). The effectiveness of social media in assisting opinion leaders to disseminate political ideologies in developing countries: The case of Malaysia. Jurnal Komunikasi: Malaysian Journal of Communication, 32(1).

Khalim Zainal, \& Salleh, N. M. (2010). Ethnic relation among the youth in Malaysia: Toward fulfilling the concept of one Malaysia. Procedia - Social and Behavioral Sciences, 9, 855858.

Leiss, W., Kline, S., \& Jhally, S. (1990). Social communication in advertising: Persons, products \& images of well-being. Routledge.

Li, L. M. (2011). A visual analysis of festive television commercials in Malaysia. MultilinguaJournal of Cross-Cultural and Interlanguage Communication, 30(3-4), 305-317.

Lombard, M., Snyder-Duch, J., \& Bracken, C. C. (2002). Content analysis in mass communication: Assessment and reporting of intercoder reliability. Human Communication Research, 28(4), 587-604. 
McCombs, M. (2002). The agenda-setting role of the mass media in the shaping of public opinion [conference paper]. Mass Media Economics 2002 Conference, London School of Economics (pp. 1-21).

Mustapha, R. (2009). Social integration among multi-ethnic students at selected Malaysian universities in Peninsular Malaysia: A survey of campus social climate. Asean Journal of Teaching and Learning in Higher Education (AJTLHE), 1(1), 35-44.

Myllyla, K. (2017). Children in advertisements: Visual representation of children in time magazine volumes of 1994,2004 and 2014 [Mater thesis, University of Jyväskylä]. https://jyx.jyu.fi/bitstream/handle/123456789/55147/1/

Ngulube, P., \& Mathipa, E. (2015). Theoretical and conceptual frameworks in the social and management sciences. In Mathipa, E. R., \& Gumbo, M. T. (Eds.), Addressing research challenges: Making headway in developing researchers (pp. 43-66). Mosala-MASEDI Publishers. https://www.researchgate.net/profile/Patrick-Ngulube/publication/

Nwachukwu, S. L., Vitell Jr, S. J., Gilbert, F. W., \& Barnes, J. H. (1997). Ethics and social responsibility in marketing: An examination of the ethical evaluation of advertising strategies. Journal of Business Research, 39(2), 107-118.

Pollay, R. (2012). Measuring the cultural values manifest in advertising. Journal of Current Issues and Research in Advertising, 6(1).

Read, S. J., \& Miller, L. C. (1995). Stories are fundamental to meaning and memory: For social creatures, could it be otherwise. Knowledge and memory: The real story. Advances in Social Cognition, 8, 139-152.

Rose, S. (2015). Management research: Applying the principles. Routledge.

Samovar, L. A. (2014). Intercultural communication: A reader. Cengage Learning.

Sarjit, S. G. (2012). Unity in diversity: Malaysian experience and approach. Research Gate, 112.

Shaari, H., Ngu, T. H., \& Raman, V. (2006). Covering race and religion: The Moorthy and Nyonya Tahir cases in four Malaysian newspapers. Kajian Malaysia, 24(1\&2), 185-201.

Shariff, S. Z. M., Sualman, I., \& Irawan, E. D. A. (2013). Fostering unity among Malaysians: A case study on the local film industry. International Journal of Humanities and Social Science, 3(10), 110-120.

Singh, M. (2014). Ethical issues and priciples related to advertising. Abhinav Journal.

Siti Zabedah Mohd Shariff, \& Ismail Sualman. (2013). Fostering unity among Malaysians: A case study on the local film industry. International Journal of Humanities and Social Science, 110-120.

Soong, K. K. (2008). Racial conflict in Malaysia: Against the official history. Race \& Class, 49(3), 33-53.

Wan Amizah Wan Mahmud, Chang Peng Kee, \& Jamaluddin Aziz. (2009). Film censorship in Malaysia: Sanctions of religious, cultural and moral values. Jurnal Komunikasi: Malaysian Journal of Communication, 25.

Yeoh, J., \& Yeoh, P. A. (2018). Competitiveness between ethnic Malays and ethnic Chinese in Malaysia. GSTF Journal of Psychology (JPsych), 2(1), 16-21.

Zubir, Z., \& Kadir, Z. A. (2012). Festive season advertisement: Analysis of Malay identity construction [conference paper]. 2012 International Conference on Humanity, History and Society, IPEDR (Vol. 34, pp. 33-37). 